\title{
New studies of decapod crustaceans from the Upper Jurassic lithographic limestones of southern Germany
}

\author{
Günter Schweigert ${ }^{1} \&$ Alessandro Garassino ${ }^{2}$ \\ 'Staatliches Museum für Naturkunde, Rosenstein 1, D-70191 Stuttgart, Germany; ${ }^{2}$ Museo civico di Storia \\ naturale, Corso Venezia 55, I-20121 Milano, Italy
}

Keywords: Crustacea, Decapoda, lithographic limestones, Upper Jurassic, Solnhofen, fossil record, diversity

\begin{abstract}
The Upper Jurassic lithographic limestones of southern Germany have long been known for their exceptional preservation of decapod crustaceans (Glaessner, 1965), similar to the Upper Cretaceous of Lebanon (Hakel, Hadjoula) and the still poorly known Callovian strata at La Voulte-sur-Rhône (France). In these non-bioturbated limestones, the decay of decapod skeletons is reduced, so that besides the heavily mineralized chelae and carapace often even delicate structures such as pleopods and antennae are preserved. Recently, new decapod material has been obtained from both scientific and commercial excavations, in part in reopened lithographic limestone quarries.
\end{abstract}

\section{Introduction}

The Upper Jurassic lithographic limestones in southern Germany outcrop at numerous localities are of different age and setting and span an area of several hundreds of kilometers (Fig. 1, Table 1) with localities in the Frankische Alb often summarized as 'Solnhofen Lithographic Limestones'. Many fossils, both in old and new collections (fossil traders), are labeled 'Solnhofen', which is highly misleading and precludes recognition of evolutionary trends

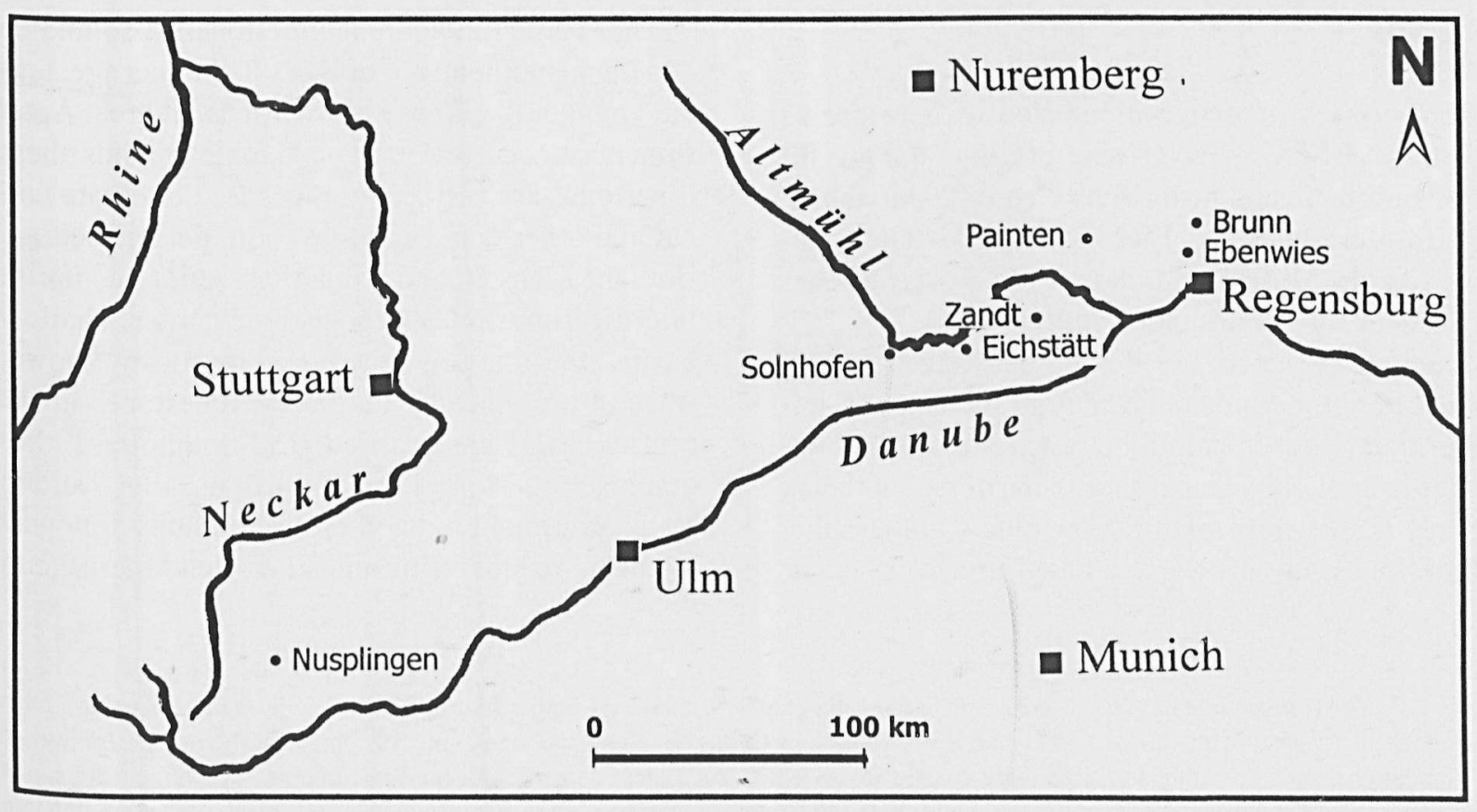

Fig. 1. Fossiliferous lithographic limestones in southern Germany. 
Table 1. Age assignments for decapod crustacean-bearing lithographic limestones in southern Germany.

\begin{tabular}{|c|c|}
\hline Locality & Stratigraphic age \\
\hline Mörnsheim, Daiting & $\begin{array}{l}\text { Early Tithonian, Hybonotum } \\
\text { Zone, uppermost part }\end{array}$ \\
\hline Solnhofen, Langenaltheim & $\begin{array}{l}\text { Early Tithonian, Hybonotum } \\
\text { Zone, upper part }\end{array}$ \\
\hline Eichstâtt, Zandt & $\begin{array}{l}\text { Early Tithonian, Hybonotum } \\
\text { Zone, lower part }\end{array}$ \\
\hline $\begin{array}{l}\text { Painten, Schamhaupten, } \\
\text { Öchselberg }\end{array}$ & $\begin{array}{l}\text { Kimmeridgian/Tithonian } \\
\text { boundary beds }\end{array}$ \\
\hline Nusplingen & $\begin{array}{l}\text { Late Kimmeridgian, Beckeri } \\
\text { Zone, Ulmense Subzone }\end{array}$ \\
\hline Brunn & $\begin{array}{l}\text { Late Kimmeridgian, Beckeri } \\
\text { Zone, Subeumela Subzone }\end{array}$ \\
\hline Ebenwies/Naab & $\begin{array}{l}\text { Late Kimmeridgian, PPseudo- } \\
\text { mutabilis Zone }\end{array}$ \\
\hline
\end{tabular}

and local differences in paleoecology. Only an in-depth knowledge of local lithologies allows recognizing the exact provenance of material. Stratigraphically well-documented material has recently been collected at several scientific excavations, and there are a number of private collectors who focus on special sites.

\section{Results}

Repositories of material referred to here are as follows: BSPM - Bayerische Staatssammlung für Palãontologie und historische Geologie, München; JME - Jura-Museum, Eichstätt; NHM - The Natural History Museum, London; SMNS - Staatliches Museum für Naturkunde, Stuttgart.

Schweigert et al. (1996) and Schweigert (2000) worked out the biostratigraphy of the Upper Kimmeridgian, but it should be noted that our knowledge of ammonite faunal succession of the Tithonian Stage is still in its infancy. The oldest lithographic limestones, in part not yet dated precisely, occur in the Regensburg (Ebenwies) area. An important locality nearby is that of Brunn, where a paper thin shale of Late Kimmeridgian age deposited in a very shallow lagoon surrounded by calcareous green algae meadows, coral reefs, and small islands, is exposed. Slightly younger (still Late Kimmeridgian) is the Nusplingen Lithographic Limestone in SW Germany, famous for its richness in fossil sharks as well as decapod crustaceans. This was deposited in a c. $100 \mathrm{~m}$ deep lagoon, surrounded by spongemicrobial mounds and islands. East of Eichstätt (Frankische Alb), several localities have yielded decapod crustaceans from lithographic limestones spanning the Kimmeridgian/Tithonian boundary, depending on a later definition of the lower boundary of the Tithonian. Excavations by staff members of the Jura-Museum Eichstätt in the siliceous lithographic limestones of Schamhaupten have resulted in a proliferation of new decapod crustacean material. In contrast, the lithographic limestones of Zandt and the more biodetritic limestones of the nearby Öchselberg have yielded a diverse, excellently preserved decapod crustacean fauna, including several new taxa. Other faunas of an age similar to those of Zandt are from quarries north of Eichstätt, e.g., Blumenberg, Schernfeld, Wintershof. Many 'old' taxa were first described from this area.

The classic lithographic limestones of Solnhofen and Langenaltheim are of Early Tithonian age, thus are younger than those of the Eichstätt area. Apart from mass occurrences of planktonic crinoids, these limestones are very poor in fossils. Vertebrate faunal and other data suggest a more pelagic setting. Both the Eichstätt and Solnhofen sections comprise micritic limestones deposited in larger, shallow basins, the margins of which are poorly known, since at present only the purest limestones in the central basins are quarried. The Solnhofen Lithographic Limestone Formation is usually overlain by a hardground or another discontinuity followed by the more biodetritic and silica-rich Moernsheim

Fig. 2 A Rosenfeldia oppeli (Woodward), Solnhofen Lithographic Limestones (upper Eichstätt Formation, Lower Tithonian), $\rightarrow$ likely from Eichstätt area (NHM 44886, holotype, Häberlein Colln). B, Erymastacus n. sp, Nusplingen Lithographic Limestone Formation (Upper Kimmeridgian), Nusplingen quarry (SMNS 64872, 2002 excavation). C, Megachela frickhingeri Schweigert, Solnhofen Lithographic Limestones (Lower Tithonian), Eichstätt (SMNS 64933, paratype, Ludwig Colln). D, Peneeid (n. gen., n. sp.), Solnhofen Lithographic Limestones (Painten Formation, Öchselberg Member, Kimmeridgian/Tithonian boundary beds), Öchselberg near Breitenhill (Bürger Colln, Bad Hersfeld). All scale bars equal $10 \mathrm{~mm}$. 


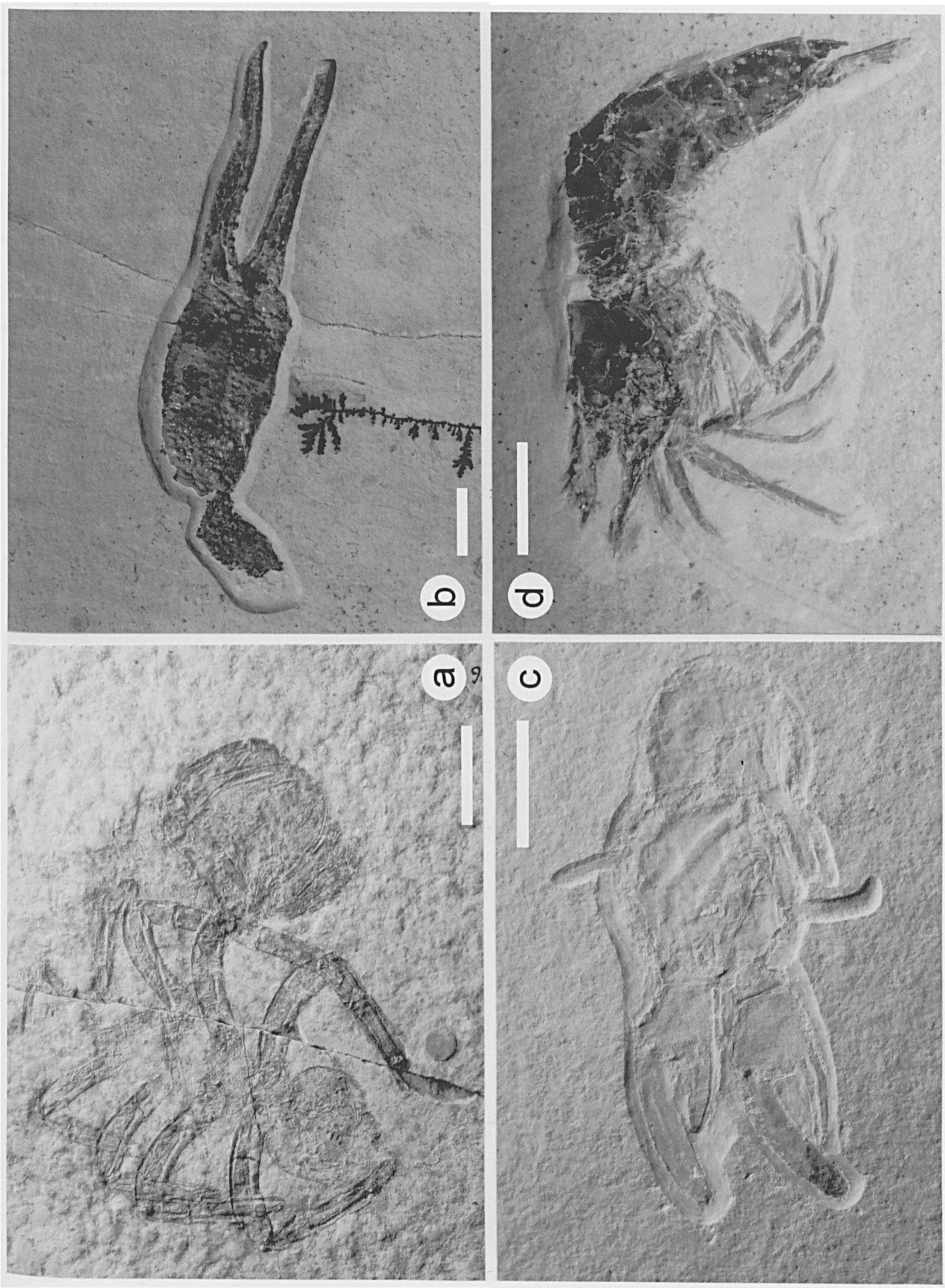




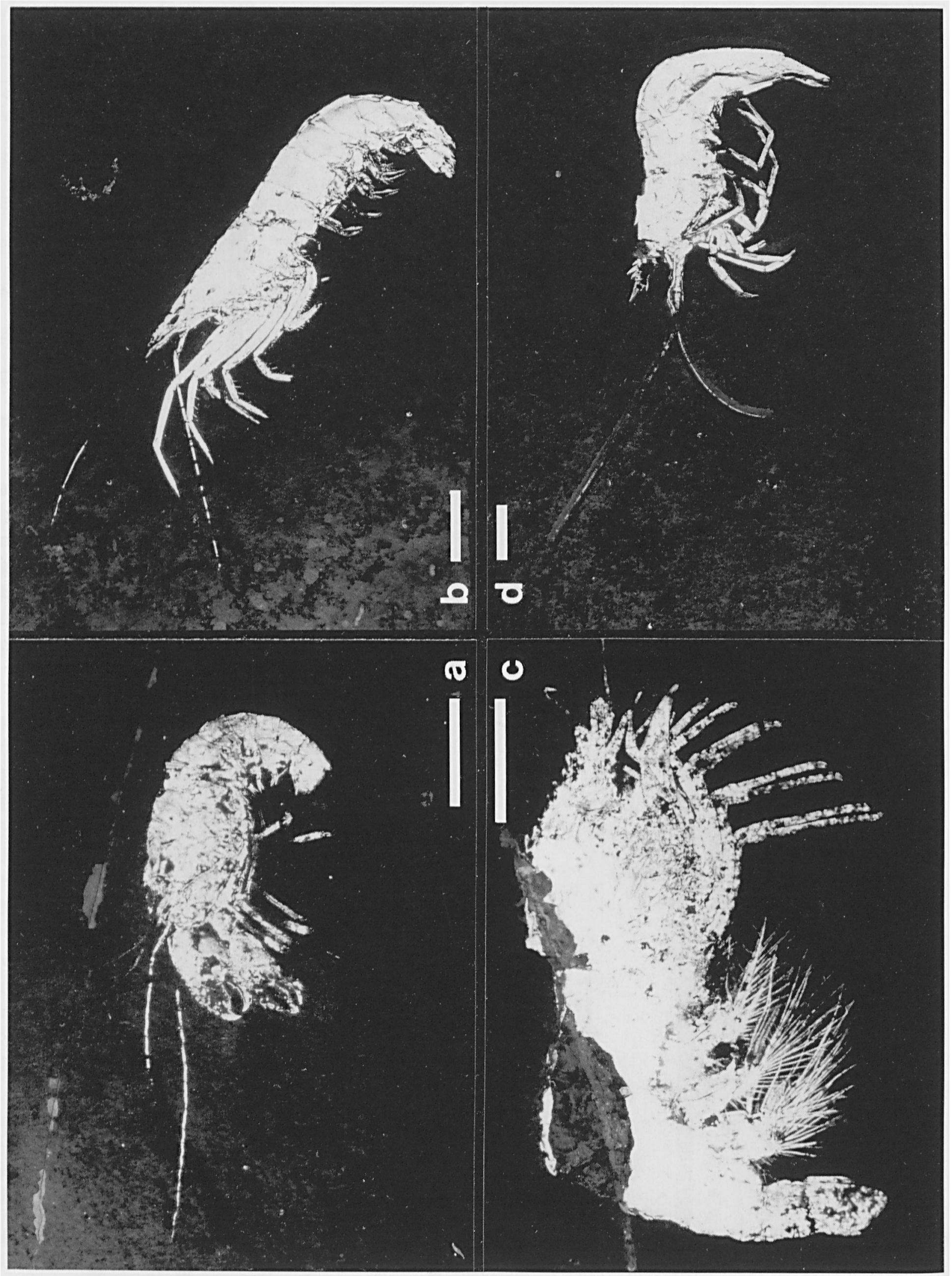


Formation, which has also yielded numerous decapod crustaceans.

\section{Discussion}

The bulk of the decapod crustaceans faunas of the lithographic limestones in southern Germany was described in nineteenth century monographs (von Schlotheim, 1820, 1822; von Münster, 1839; Oppel, 1861,1862 ). Discoveries of extant eryonids during deep-sea expeditions triggered the study of fossil forms (e.g., von Knebel, 1907). In the first half of the twentieth century, both Beurlen and Glaessner almost ignored decapods from the lithographic limestones in their scientific work. In recent years, $c$. 56 valid taxa from the Frankische Alb and four others from the isolated locality of Nusplingen (Schwaben) have been described, and only a few of these have been briefly revised by Förster $(1966,1967,1973$, 1977). Following his untimely death in 1987 , the study of fossil decapod crustaceans from Germany declined.

From the late 1990s onwards, scientific excavations both in eastern Bayern (Brunn), the southern Frankische Alb (Schamhaupten) and at Nusplingen, has rekindled research activities (Polz, 1999, 2000; Schweigert 2001a,b,c; Schweigert \& Dietl, 1999; Schweigert et al., 2000; Schweigert \& Röper, 2001). It became obvious that both for paleoenvironmental reconstructions and systematic paleontology, it is necessary to separate the fossil material of each locality. Another strong pulse is given by the monographic documentation of 'Solnhofen' fossils stored in various museums around the world as well as in several private collections (Frickhinger, 1994, 1999). Frickhinger's aim was a complete documentation of all taxa of animals and plants from the "Solnhofen" limestones. From this otherwise unavailable data pool the existence of many new'taxa became clear. Additionally, good material of rare or poorly pre- served taxa came to light, which often allowed a revision of these.

Future research into decapod crustaceans from the lithographic limestones of southern Germany has many aspects. Firstly, a modern revision of the taxa is necessary, in which the stratigraphic age, provenance, and taphonomy is included. Most of the type material is still available, but some taxa are in fact nomina dubia. The bulk of the types from the Frankische Alb are in museums in München (Münster and Oberndorfer collections) and in Berlin (von Schlotheim and Redenbacher collections). Few others survive in the Senckenberg Museum at Frankfurt am Main (H. von Meyer Colln), at the Geiseltal Museum (Halle/Saale; Germar Colln), and at the Natural History Museum (London; Häberlein Colln). The types from Nusplingen are almost exclusively housed at the Staatliches Museum für Naturkunde Stuttgart (O. Fraas Colln).

For mány taxa, lectotypes have never been designated, and therē are still some doubtful genera and species. New topotypes in better preservation and the use of ultraviolet light (Fig. 2A-D) often allow a more detailed redescription. Unfortunately, the use of ultraviolet light does not work with decapods from Zandt, which otherwise includes the best material. Secondly, a larger amount of new taxa, approximately 15-20, still awaits description, documenting most orders of Jurassic decapods. Some of them are easily assigned to described genera, while others are completely new and demonstrate the incompleteness of our present knowledge of decapod diversity in the Upper Jurassic. In several groups, even in those held to be conservative, evolutionary trends have been observed, e.g., in the penaeid genus Antrimpos (Schweigert, 2001b), or in the scyllarid Cancrinos. In both genera, correlation between provenance and stratigraphic age with described species has become obvious, suggesting they most likely represent successive chronospecies. In others, however, no morphological changes are recognizable in populations of different ages.

\section{$\leftarrow$}

Fig. 3. A, Malmuncina wulfi Schweigert \& Garassino, Solnhofen Lithographic Limestones (Painten Formation, Ochselberg Member, Kimmeridgian/Tithonian boundary beds), Öchselberg near Breitenhill (JME Ti 2003/1, holotype, Wulf Colln). B, Udora brevispina von Münster, Solnhofen Lithographic Limestones (Upper Eichstätt Formation, Lower Tithonian), Eichstätt area (BSPM 1964 XXIII 593). C, Eukyphìd (n. gen., n. sp.), Solnhofen Lithographic Limestones (Upper Eichstätt Formation, Lower Tithonian), Eichstätt area (SMNS 64943, Kümpel Colln). D, Penaeid (n. gen., n. sp.), Solnhofen Lithographic Limestones (Upper Eỉchstätt Formation, Lower Tithonian), Eichstâtt area (SMNS 64945, Kümpel Colln). All scale bars equal $10 \mathrm{~mm}$. 
Reptants are mostly represented by molts, except for Mecochirus longimanatus (von Schlotheim), one of the commonest decapods in the Solnhofen area, and few eryonids (Cycleryon $\mathrm{sp}$.) with their last trails and the dead body preserved on the sea floor.

In eryonids, sexual dimorphism has been demonstrated for Cycleryon propinquus (von Schlotheim), assumed to be the male, and $C_{x}$ spinimanus (Germar), thought to be the female (Schweigert, 2001a). A unique, incompletely preserved specimen (Fig. 3A), described by Woodward (1866) as Eryon oppeli, represents a Late Jurassic representative of Rosenfeldia, a previously monospecific genus from the Upper Triassic. Although hundreds of eryonids have been collected from the Upper Jurassic lithographic limestones since the original description of the type of 'Eryon' oppeli, no other specimen has come to light.

Among the Astacidea, erymids are the commonest. However, apart from the relatively abundant Eryma modestiformis (von Schlotheim) several other species occur, differing mainly in details of their chelae, whereas the features of the carapace are not significant enough for a specific differentiation. Another group of erymids is characterized by chelae with elongate pincers bearing strong and widely spaced teeth. Beurlen (1928) included these in Erymastacus, whereas Förster (1966) ignored this character and lumped them again in Eryma s. str. Although isolated chelae of Erymastacus occur frequently in various Middle and Upper Jurassic beds in southern Germany and elsewhere, the records from lithographic limestones are extremely rare and material is mostly incomplete. In addition to Erymastacus major (Oppel), another species of this genus occurs in the Kimmeridgian at Nusplingen, based on a single isolated cheliped (Fig 2B). Another astacidean family, the Uncinidae, was previously assumed to be confined to the Upper Liassic; this is obviously a collecting bias, because three specimens of a Late Jurassic uncinid (Fig. 2A) are now known from Zandt, Öchselberg, and from the Eichstätt area (Schweigert \& Garassino, 2003).

Thalassinoids are rarely found in lithographic limestones. In addition to the long-known Magila and Etallonia, the new genus Megachela (Fig. 3C) with an extraordinarily prolonged fixed finger occurs sporadically at Eichstätt and Zandt (Schweigert,
2003). All three genera are included in the Axiidae, in which they represent a primitive clade joined by a well-developed diaeresis.

Within the natantians, the recent new discoveries are enormous. Especially the eukyphids formerly known by very few but morphologically strikingly heterogeneous genera (Hefriga, Udora, Udorella, and Blaculla) are much more diverse. Amongst them, only the well-known Hefriga serrata von Münster (see Förster, 1967) appears to be quite common, although mostly incompletely preserved or juvenile, whereas the other taxa are extremely rare. Again, ultraviolet light analysis provides fine details otherwise barely visible, such as delicate spines of the pereiopods or pleopods and uropods in Udora brevispina von Münster (Fig. 2B). One of the recently discovered new eukyphid forms is the monospecific Schmelingia, which exhibits prolonged first pereiopods bearing strong chelae (Schweigert, 2002). Another strange, yet unnamed, eukyphid decapod, which cannot be assigned to a modern family, bears large, feather-like lateral appendices at the pleopods of all somites (Fig. 2C), which must have had a special function, not only for hatching the eggs.

Obviously, the habitats of many of these new forms were far away from the place of subsequent entombment, with their exuviae drifted only in exceptional cases into the anoxic basins, hostile to benthic organisms. Amongst penaeids, Antrimpos is the most abundant genus, accompanied by several species of Aeger and Acanthochirana. Also in penaeids, new species and even new genera are recorded (Fig. 2D; Fig. 3D). Genera that originally included more than a single species, often need revision. For example, 'Bylgia' hexadon von Münster and ' $B$.' haeberleini von Münster are best referred to a new genus, with $B$. spinosa as the type species, already designated by Oppel (1862). A new species of Bylgia, which differs from B. spinosa in its larger rostrum bearing more dorsal spines has recently been discovered in the Oechselberg Shales. Other rare peneid species such as Koelga curvirostris von Münster, originally only known from a single, poorly preserved specimen, have lately been found in several specimens and in a much better condition.

Isolated carapaces of prosopids are very abundant in the "normal' marly limestone lithology of 
the Upper Jurassic in southern Germany, beyond the laminated facies. In the lithographic limestones, however, they are almost absent. Only at few localities (Öchselberg near Breitenhill) do prosopids occur sporadically. Usually, they are poorly preserved because of their weak mineralization, but occasionally carapaces preserve even the pereiopods.

\section{Acknowledgements}

We thank G. Schairer and M. Nose (both München), T. Becker and C. Neumann (both Berlin), and A. Ross (London) for their assistance in locating and studying type material. For access to well- preserved new decapod material from the lithographic limestones, we are indebted to P. Bürger (Bad Hersfeld), R. Frattigiani (Laichingen), K.A. Frickhinger(Emmering), G. Koschny (Bad Soden), D. Kümpel (Wuppertal), P. Rüdel (München), and M. Wulf (Rödelsee).

\section{References}

Beurlen K. 1928. Die Decapoden des Schwäbischen Jura mit Ausnahme der aus den oberjurassischen Plattenkalken stammenden. Palaeontogr. 70: 115-278.

Förster R. 1966. Über die Erymiden, eine alte konservative Familie der mesozoischen Dekapoeden. Palaeontogr. 125: 61-175.

Fôrster R. 1967. Zur Kenntnis natanter Jura-Dekapoden. Mitt. Bayer. Staatssamml. Paläont. hist. Geol. 7: 157174.

Förster R. 1973. Untersuchungen an oberjurassischen Palinuridae. Mitt. Bayer. Staatssamml. Paläont. hist. Geol. 13: 31-46.

Förster R. 1977. Untersuchungen an jurassischen Thalassinoiden (Crustacea, Decapoda). Mitt. Bayer. Staatssamml. Paläont. hist. Geol. 17: 137-156.

Frickhinger KA. 1994. Die Fossilien von Solnhofen. Korb: Goldschneck.

Frickhinger KA. 1999. Die Fossilien von Solnhofen, 2. Korb: Goldschneck.

Glaessner MF, 1965. Vorkommen fossiler Dekapoden (Crustacea) in Fisch-Schiefern. Senckenb. Leth. 46a: 11-122.

Knebel W von 1907. Die Eryoniden des oberen Weissen Jura. Arch. Biont. 2(2): 193-233.

Münster $G$ von 1839. Decapoda Macroura. Abbildung und Beschreibung der fossilen langschwãnzigen Krebse in den Kalkschiefern von Bayern, Beitr. Petrefactenkde 2: 1-88.

Oppel A. 1861. Die Arten der Gattungen Eryma, Palaeastacus, Magila und Etallonia, Jh. Ver, vaterl. Naturk. Württ. 17; 355-361.

Oppel A. 1862. Über jurassische Crustaceen. Palaeont. Mitt. 1: 1-120.
Polz H. 1999. Etallonia hoellorum sp. nov. (Crustacea, Decapoda, Axiidae) aus dem Oberkimmeridgium der sũdlichen Frankenalb. Archaeopteryx 17: 33-39.

Polz H. 2000. Glyphea viohli sp. nov. (Crustacea: Decapoda: Glypheidae) aus den Solnhofener Plattenkalken. Archaeopteryx 18: 17-25.

Schlotheim EF von 1820. Die Petrefactenkunde auf dem jetzigen Standpunkte durch die Beschreibung seiner Sammlung versteinerter und fossiler Überreste des Thier- und Pflanzenreichs der Vorwelt erläutert. Gotha: Becker.

Schlotheim EF von 1822. Nachträge zur Petrefactenkunde, 1. Gothax Becker.

Sehweigert G. 2000. New biostratigraphic data from the Kimmeridgian/Tithonian. In: Hall RL, Smith P. (eds). Advances in Jurassic Research 2000. GeoRes. Forum 6: 195-202.

Schweigert G. 2001a. Dimorphismus bei Krebsen der Gattung Cycleryon (Decapoda, Eryonidae) aus dem Oberjura Süddeutschlands. Stuttg. Beitr. Naturk. B305: 1-12.

Schweigert G. 2001b. Eine neue Art der Gattung Antrimpos Münster (Crustacea, Decapoda, Peneidae) aus dem Nusplinger Plattenkalk (Oberjura, Ober-Kimmeridgium, SWDeutschland). Stuttg. Beitr. Naturk. B307: 1-33.

Schweigert G. 2001e. The late Jurassic decapod species Aeger tipularius (Schlotheim, 1822) (Crustacea: Decapoda: Aegeridae). Stuttg. Beitr. Naturk. B309: 1-10.

Schweigert G. 2002. Zwei neue Gamelen (Decapoda: Dendrobranchiata, Eukyphida) aus oberjurassischen Plattenkalken Süddeutschlands. Stuttg. Beitr. Naturk. B323: 1-11.

Schweigert G. 2003. Megachela frickhingeri n. g. n. sp. (Crustacea: Decapoda: Thalassinoidea: Axiidae) aus dem Solnhofener Plattenkalk (Ober-Jura, Bayern), Stuttg. Beitr. Naturk.

Schweigert G, Dietl G. 1999. Neubeschreibung von "Eryon longipes $\mathrm{O}$. Fraas" (Crustacea, Decapoda, Eryonidea) aus dem Nusplinger Plattenkalk (Ober-Kimmeridgium, Schwäbische Alb), Stuttg. Beitr. Naturk. B274: 1-10.

Schweigert G, Dietl G, Röper M. 2000. Die Panzerkrebse der Familie Erymidae Van Straelen (Crustacea, Decapoda) aus dem Nusplinger Plattenkalk (Ober-Kimmeridgium, Schwäbissche Alb) im Vergleich mit fränkìschen Vorkommen. Stuttg. Beitr. Naturk. B285: 1-14.

Schweigert G, Garassino A. 2003. Malmuncina wulfi n. g. n. sp., the first uncinid decapod (Crustacea: Decapoda: Astacidea) from the Upper Jurassic. Stuttg. Beitr. Naturk. B336: 1-8.

Schweigert G, Krishna J, Pandey B, Pathak DB. 1996. A new approach to the correlation of the Upper Kimmeridgian Beckeri Zone across the Tethyan Sea. $N . J b$. GeoL. Paläont. Abh. 202: 345-373.

Schweigert G, Röper M. 2001. Neue Krebse der Gattung Palaeastacus (Crustaceax Decapoda: Erymidae) aus oberjurassischen Plattenkalken Süddeutschlands. Stuttgarter Beitr. Naturk. B313: 1-10.

Woodward H. 1866. Notes on the species of the genus Eryon Desmarest, from the Lias and Oolite of England and Bavaria. Quart. Jour. Geol. Soc. Lond. 22: 500.

Received: 25 February 2003 